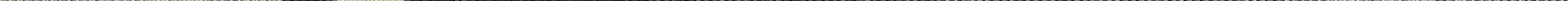




\section{PAISAGENS CULTURAIS: POR UM OLHAR DIALOGADO}

\section{Vanessa Gayego Bello Figueiredo}

Arquiteta e urbanista. Doutora em planejamento urbano e regional pela FAU/USP, docente na Faculdade de Arquitetura e Urbanismo da PUC-Campinas, ex-Subprefeita de Paranapiacaba e Pq. Andreense/Santo André

\section{Andrey Schlee}

Diretor do Departamento de Patrimônio Material do IPHAN

\section{INTRODUÇÃO}

O progressivo alargamento daquilo que é considerado objeto de interesse para a preservação, pode ser destacado em dois grandes momentos. Primeiramente, naquele em que se supera a noção de monumento, de um bem cultural como elemento destacado e isolado (natural ou construído), saltando para o reconhecimento de conjuntos arquitetônicos e urbanos, da arquitetura modesta, centros e cidades históricas, embora reconhecendo-os apenas em seus valores estéticos e históricos. E, recentemente, agregando outros valores e significados rumo ao reconhecimento da diversidade cultural, por meio dos ditos "novos patrimônios", sobretudo aqueles de natureza imaterial, e os de característica sistêmica e integrada, como se pretende com a noção de paisagem cultural. Este último, ainda, identificado em diversas escalas territoriais, unidades intraurbanas ou sistemas regionais de paisagem. Esta evolução conceitual, ao tempo em que amplia a noção de patrimônio preservação, enfim, à gestão. 
No Brasil, esta evolução do conceito de patrimônio cultural, assumido pela Constituição Federal de 1988, e o aumento da noção e da prática da cidadania (envolvendo a ampliação dos direitos civis, políticos e sociais), estão a exigir outro olhar para o contexto cultural. Um olhar dialogado, capaz de considerar corretamente os valores culturais em jogo ou em risco, sejam eles materiais e imateriais, e, simultaneamente, ouvir os anseios da comunidade que deseja construir, de forma cada vez mais participativa, um presente e um futuro com qualidade para todos.

É neste contexto que o IPHAN - Instituto do Patrimônio Histórico e Artísitico Nacional, e outras instituições responsáveis pela preservação do patrimônio cultural no Brasil, têm se deparado com ações inéditas de movimentos populares ou grupos sociais em defesa de determinados valores culturais. Podemos citar a ação civil pública que solicitou a nulidade do ato do IPHAN que autorizava obras no Parque do Flamengo no Rio de Janeiro; o Movimento Ocupe Estelita, que reuniu um significativo número de cidadãos com apoio do Ministério Público Federal, solicitando o tombamento emergencial do Pátio Ferroviário das Cinco Pontas de Recife (em Pernambuco), visando impedir a construção de 13 altas torres multiuso; o movimento em prol do Parque Augusta em São Paulo; o movimento pró-Paranapiacaba que resultou no tombamento, aquisição e gestão participativa da vila ferroviária em Santo André -SP; o movimento pró Fabrica São Luiz em Itu-SP, que salvou parte dos armazéns da primeira fábrica de tecidos de São Paulo da demolição autorizada pelos próprios órgãos de preservação do patrimônio, dentre outros. Em todos os casos, pelo menos, duas questões devem ser consideradas: a quem compete a construção e condução de políticas urbanas no Brasil e qual a abrangência e eficácia das ações das instituições de patrimônio ? Por outro lado, fica evidente o necessário protagonismo do tema "gestão" - gestão do território e, também, gestão integrada e participativa dos bens culturais protegidos.

Faz-se necessário lembrar que nossa Constituição Cidadã em vigor definiu que a política de desenvolvimento urbano deve ser executada pelo Poder Público municipal, a partir de diretrizes gerais fixadas em lei, objetivando "ordenar o pleno desenvolvimento das funções sociais da cidade e garantir o bem-estar de seus habitantes". Também foi ela que determinou que o Poder Público, "com a colaboração da comunidade, promoverá e protegerá o patrimônio cultural brasileiro, por meio de inventários, registros, vigilância, tombamento e desapropriação, e de outras formas de acautelamento e preservação". 
Buscando responder positivamente ao desejo constitucional, o IPHAN coordenou neste milênio a construção do Decreto n 3.551/2000 - que instituiu o Registro dos Bens Culturais de Natureza Imaterial e a Política Nacional do Patrimônio Imaterial - e produziu a Portaria $\mathrm{n}^{\circ}$ 127/2009 - que estabeleceu a Chancela da Paisagem Cultural. Entre os evidentes avanços dos dois instrumentos, cabe mencionar a necessária anuência dos "detentores" como condição para o registro de um determinado bem; e o necessário estabelecimento de um "pacto" entre os diferentes agentes envolvidos "visando a gestão compartilhada da porção do território nacional" a chancelar. Anuência e pacto pressupõem aprovação, consentimento e acordo. Portanto, implicam em estabelecimento de diálogo prévio. Diálogo entre os órgãos de preservação cultural e a sociedade organizada, entre o IPHAN e os demais agentes institucionais.

Desta forma, os artigos reunidos na presente publicação sobre a experiência de reconhecimento e gestão de paisagens culturais no Brasil, revelam como este olhar dialogado tem sido construído entre as instituições e as comunidades, buscando focar a interdisciplinaridade e o território como chaves na formulação de políticas integradas que superem dicotomias clássicas entre os papéis do Estado e da Sociedade, mas também na gestão dos patrimônios natural, cultural, material e imaterial.

Algumas experiências, como as de Paranapiacaba e Iguape no Estado de São Paulo, e do Serro e do Alto do Rio São Francisco em Minas Gerais, construíram processos, métodos e instrumentos que lograram conquistas importantes de diálogo que resultaram em ações conjuntas, corresponsáveis e legitimadas de preservação cultural e gestão integrada.

Particularmente, no tocante à experiência institucional do IPHAN, os artigos apresentam diferentes momentos institucionais na busca do aprimoramento dos instrumentos e metodologias de ação para a abordagem de bens culturais complexos, como as paisagens culturais. Neles, o leitor encontrará referências aos projetos Roteiros Nacionais de Imigração, a Valorização da Paisagem Cultural das Missões Jesuíticas dos Guaranis e a Paisagem Cultural do Rio de Janeiro reconhecida pela UNESCO como patrimônio mundial em 2012, conceitualmente distintos entre si, mas fundamentais para a consolidação de uma política, que se revelou por meio do desenvolvimento do Sistema Integrado de Conhecimento e Gestão, do Projeto Barcos do Brasil e da elaboração da própria Portaria n 127/2009. Uma política que, amplamente discutida dentro e fora do IPHAN, ainda busca de dar o salto qualitativo essencial, o do olhar dialogado. 